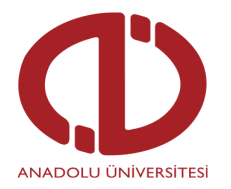

Açıköğretim Uygulamaları ve Araştırmaları Dergisi AUAd

https://dergipark.org.tr/tr/pub/auad

Gönderim: 19.04 .2021

\title{
Açık ve uzaktan öğrenenlerin sınavlarda çoktan seçmeli soruları boş bırakma davranışlarının incelenmesi
}

\author{
Nejdet KARADAĞ $\breve{a}^{\mathrm{a}}$ \\ a Anadolu Üniversitesi Açıköğretim Fakültesi, ORCID: 0000-0002-9826-1297
}

\begin{abstract}
Özet
Çoktan seçmeli testler açık ve uzaktan öğrenmede öğrenenlerin değerlendirilmesinde yaygın olarak kullanılan objektif ölçme araçlarından biridir. Bunun en önemli nedeni, çoktan seçmeli testlerin uygulama ve değerlendirme açısından kullanışlı olmasıdır. Şans başarısı içermesi çoktan seçmeli testlere yöneltilen en önemli eleştirilerdendir. Çoktan seçmeli testlerde şans başarısını ortadan kaldırmak için çeşitli yöntemler denenmiştir. Bu yöntemlerden biri de yanıtlayıcıların cevabını bilmedikleri soruları boş bırakmalarını gerektiren yanlış cevapların doğru cevap sayısını eksiltmesi uygulamasıdır. Bu çalışmada, Anadolu Üniversitesi Açıköğretim Sistemi'nde yüz yüze gerçekleştirilen 2019-2020 Öğretim Yılı Güz Dönemi ara ve dönem sonu sınavlarında 3’ü sözel ve 3'ü sayısal olmak üzere toplam 6 derste öğrenenlerin çoktan seçmeli soruları boş bırakma davranışları incelenmiştir. Madde analizi verilerine göre testlerden yüksek puan alan (üst grup) ve düşük puan alan (alt grup) öğrenenlerin soruları boş bırakma durumu soruların güçlük düzeyi, sınav dönemi ve ders türü değişkenleri açısından incelenmiştir. İlişkisel tarama modelinde yürütülen araştırmada verilerin analizinde Spearman Sıralama Korelasyonu ve bağımsız örneklem t-testi kullanılmıştır. Uygun durumlarda veriler oransal grafikler kullanılarak anlamlandırılmıştır. Elde edilen sonuçlar; soruları boş bırakma oranlarının dönem sonu sınavında ara sınava göre, sayısal içerikli derslerde sözel içerikli derslere göre daha fazla olduğunu ve soruların güçlük düzeyi arttıkça boş bırakma eğiliminin arttığını ortaya koymuştur.
\end{abstract}

Anahtar Sözcükler: Açık ve uzaktan öğrenme, öğrenen değerlendirmesi, çoktan seçmeli testler, şans başarısı

\section{Examination of open and distance learners' behavior of leaving multiple-choice questions unanswered in exams}

\begin{abstract}
Multiple-choice tests are one of the widely used objective measurement tools in the assessment of learners in open and distance learning. The most important reason for this is that multiple-choice tests are practical in terms of application and evaluation. However, having the guessing effect is one of the most important criticisms directed at multiple-choice tests. Several methods have been used to eliminate the effect of such guessing. One of these methods is penalizing the test-taker by reducing the number of correct answers based on the number of incorrect answers, which urges test-takers to skip the questions whose answers they do not know. This study analyzed students' behavior of leaving multiple-choice questions unanswered in the Fall semester midterm and end-of-semester exams for 6 courses ( 3 verbal and 3 numerical) conducted face-to-face at Anadolu University Open education system in the 2019-2020 academic year. Based on item analysis data, the question-skipping status of students who scored high (upper group) and low (lower group) was examined by the variables of question difficulty level, exam period, and course type. The Spearman Rank Correlation and independent sample t-test were used to analyze the data in the research conducted in the correlational survey model. When appropriate, the data were interpreted using proportional graphs. The results showed that the rates of leaving questions unanswered were higher in the end-of-term exam than in the midterm exam, in numerical courses than in verbal courses, and the proportion of skipping questions increased in line with the difficulty level.
\end{abstract}

Keywords: Open and distance learning, assessment of learners, multiple-choice tests, guessing 


\section{Giriş}

Eğitim; girdiler, süreç, çıktılar ve kontrol bileşenlerinden oluşan bir sistem olarak tanımlanabilir. Bu sistemin kontrol bileşeni ölçme ve değerlendirmedir (Baykul, 1992; Gelbal, 2013). Öğretim programlarında yer verilen derslerde belirlenen kazanımlara öğrenenlerin ne derece ulaştıkları, öğrenme sürecinde hangi konularda öğrenme eksiklerinin ortaya çıktığ 1 , öğrenme kaynaklarının ve öğretim sürecinin ne kadar etkili olduğu gibi soruların yanıtlarına ölçme ve değerlendirme etkinlikleri sonunda ulaşılır. Bu nedenle ölçme ve değerlendirme, eğitim sisteminin diğer bileşenlerine geribildirim sağlayan vazgeçilmez ve temel unsur olarak kabul edilir.

Öğrenenlerin birbirlerinden ve öğrenme kaynaklarından zaman ve/veya mekân bağlamında uzakta olduğu, birbirleriyle ve öğrenme kaynaklarıyla etkileşimlerinin uzaktan iletişim sistemlerine dayalı olarak gerçekleştirildiği açık ve uzaktan öğrenmede (Özkul ve Aydın, 2012), öğrenenleri değerlendirmede kullanılan ölçme araçları yüz yüze öğrenme ortamında kullanılan ölçme araçlarına göre daha sınırlıdır. Özellikle derse kayıtlı öğrenen sayısının yüz binin üzerinde olduğu mega üniversiteler başta olmak üzere diğer açık üniversitelerde öğrenenleri değerlendirmede ağırlıklı olarak objektif testler sınıfında yer alan çoktan seçmeli testler kullanılmaktadır (Chaudhary ve Dey, 2013; Karadağ ve Özgür, 2020; Zhang, Tsui, Jegede, Ng ve Kowk, 2002). Açıöğretim, İktisat ve İşletme Fakültelerinden oluşan Anadolu Üniversitesi Açıöğretim Sistemi'nde de öğrenenlerin değerlendirilmesinde ödev/proje, açık uçlu sorular, e-portfolyo ile birlikte çoktan seçmeli testler kullanılmaktadır. Türkiye'de 2016-2017 öğretim yılından itibaren açık ve uzaktan yükseköğretim programlarında çoktan seçmeli testlerin uygulandığı sınavlarda elde edilen puanları şans başarısından arındırma ve öğrenenleri değerlendirmede kurumlar arasında birliğin sağlanması amacıyla sınavlarda "dört yanlış yanıtın bir doğru yanıtı eksiltmesi” uygulamasına geçilmiştir.

Bu çalışmada, Açıköğretim Sistemi'nde 3'ü sözel ve 3'ü de sayısal olmak üzere toplam 6 derste öğrenenlerin dört yanlışın bir doğru yanıtı eksiltmesi uygulamasına bağlı olarak çoktan seçmeli soruları boş/cevapsız bırakma durumu incelenmiştir. Araştırmayla, seçilen derslerin madde analizi verilerinde yükssek puan alan öğrenenler (üst grup) ile düşük puan alan öğrenenler (alt grup) arasında soruları boş bırakma davranışı bakımından farklılık olup olmadığı belirlenmeye çalışılmıştır. Elde edilen sonuçların açık ve uzaktan öğrenme hizmeti veren kurumların uygulamalarına yol göstereceği düşünülmüştür. 


\section{Araștırma Sorunsalı}

Türkiye'de açık ve uzaktan yükseköğretim programlarında dört yanlışın bir doğru yanıtı eksiltmesi uygulamasının başlamasıyla öğrenenlerin cevabını bilmedikleri soruları boş bırakma eğiliminde oldukları gözlenmiştir. Soruları boş bırakma davranışı bakımından sınavlardan yüksek puan alan öğrenenler (üst grup) ile düşük puan alan öğrenenler (alt grup) arasında bir fark olup olmadığının ve öğrenenlerin soruları boş bırakmalarında hangi değişkenlerin etkili olduğunun belirlenmesi bu araştırmanın problemini oluşturmuştur. Araştırmayla, soruların güçlük düzeylerinin boş bırakma davranışını nasıl etkilediği, sınav döneminin ve derslerin sayısal ya da sözel içerikli olmasının boş bırakma davranışı açısından belirleyici bir değişken olup olmadığı belirlenmeye çalışılmıştır. Bu kapsamda araştırmada aşağıdaki sorulara yanıt aranmıştır:

1. Üst ve alt gruplarda yer alan öğrenenlerin soruları boş bırakma oranları soruların güçlük düzeyine göre farklılık göstermekte midir?

2. Üst ve alt gruplarda yer alan öğrenenlerin soruları boş bırakma oranları sınav dönemine (ara/dönem sonu) göre farklılık göstermekte midir?

3. Üst ve alt gruplarda yer alan öğrenenlerin soruları boş bırakma oranları ders türüne (sözel/sayısal içerikli) göre farklılık göstermekte midir?

Araştırma, 3’ü sözel ve 3’ü de sayısal olmak üzere toplam 6 dersin yüz yüze gerçekleştirilen 2019-2020 öğretim yılı güz dönemi ara ve dönem sonu sınavları madde analizi verileriyle sinırlıdır.

\section{Alanyazın}

\section{Çoktan Seçmeli Testler}

Açık ve uzaktan öğrenmede öğrenenlerin değerlendirilmesinde çoktan seçmeli testler, ödev, proje, açık uçlu sorular, kısa sınavlar, e-portfolyo, senkron ve asenkron tartışma kayıtları, öz değerlendirme ve akran değerlendirme gibi birçok ölçme aracı ve yöntem kullanılmaktadır. Büyük kitlelere merkezi sınavların uygulanması söz konusu olduğunda ölçme aracı olarak en çok çoktan seçmeli testler tercih edilmektedir. Çoktan seçmeli testler; doğru-yanlış testleri, eşleştirme testleri ve bilgisayar tarafından puanlanabilen diğer testlerle birlikte objektif ölçme araçları arasında yer almaktadır (Simonson vd., 2012).

Gelbal (2013), çoktan seçmeli testleri diğer ölçme araçlarından ayıran özellikleri şöyle siralamıştır: 
- Doğru cevabın çoğu zaman maddenin içinde verilmesi

- Test süresinin önemli bir kısmının maddenin okunmasına ve doğru cevabın bulunmasina ayrilmas 1

- Puanlamanın objektif olması

- Uygulanmasinın kolay olması

- Puanlama süresinin kısa olması

- Soru sayısının fazla olmasi

- Cevaplamanın sadece işaretleme yoluyla yapılabilmesi

- Hazırlanma süresinin uzun olmasi

- Şans başarısı içermesi

- İleri düzeydeki davranışları ölçmede yetersiz kalması

Çoktan seçmeli testlerin yukarıda sayılan özelliklerinden bazıları olumlu bazıları da olumsuz olarak değerlendirilmektedir. Büyük kitlelere uygulanmasının kolay olması, puanlama süresinin kısa olması ve soru sayısının çok olması sayesinde kapsam geçerliği yüksek sinavlar hazırlanabilmesi (Baykul, 2000; Miller, Linn ve Gronlund, 2012; Umay, 1997) çoktan seçmeli testlerin öne çıkan olumlu özellikleridir. Çoktan seçmeli testlerin öğrenenlerin değerlendirilmesinde yaygın olarak kullanılmasında yukarıda sayılan olumlu özelliklerinin yanında gerek biçimlendirici değerlendirme gerekse düzey belirleyici değerlendirmede nesnelliği sağlıyor olması da etkili olmaktadır (Adiga vd., 2021). Nesnellik, soruların herkes için aynı olan tek bir doğru cevabının olması ve puanlamanın tüm öğrenenler için standart ve güvenilir bir şekilde bilgi işlem yöntemleriyle yapılmasıyla ilgilidir.

Çoktan seçmeli soruların hazırlanmasının uzun zaman alması soru yazmanın alan bilgisiyle birlikte teknik yeterlik ve deneyim de gerektirmesinden kaynaklanmaktadır. Sorular hazırlanırken Bloom ve meslektaşları tarafından 1956 yılında yayımlanan bilişsel alanda eğitim hedeflerinin aşamalı sınıflandırılması göz önünde bulundurulmaktadır. Temel amacı; öğreticilerin öğrenenlerden neyi bilmelerini istediklerinin basitten karmaşığa aşamalı bir şekilde sıralanması olan sınıflama başlangıçta bilgi, kavrama, uygulama, analiz, sentez ve değerlendirme basamaklarından oluşmuştur (Yurdabakan, 2012). Daha sonra sınıflama Bloom ile birlikte aynı ekipte yer alan Krathwohl ve meslektaşları tarafından 2002 yılında güncellenmiştir. Güncellenen sınıflama bilişsel süreç ve bilgi boyutu olmak üzere iki boyutlu bir yapıya dönüştürülmüş ve yeni sınıflamada aşamaların isimleri hatırlama, anlama, uygulama, analiz, değerlendirme ve üretme/yaratma şeklinde belirlenmiştir (Yurdabakan, 2012). Yazılan çoktan seçmeli her bir sorunun bu aşamalarda belirtilen kazanım düzeyine uygun olması gerekir. Buna göre; hatırlama düzeyinde bir soru güçlük olarak "kolay " şeklinde 
nitelenirken üretme/yaratma düzeyinde bir soru "zor" olarak nitelenmektedir. Çoktan seçmeli test planı yapılırken testte hangi düzeyden kaç soru olacağını gösteren hedef-içerik tablosu olarak da adlandırılan (Demirel, 2007) belirtke tablosu hazırlanır. Bu tabloyla uygulanacak testlerde yer verilen her bir sorunun sınıflamadaki hangi basamağa ait olduğu ve testin genel olarak tahmini güçlüğü de belirlenmiş olur.

Şans başarısı içermesi ve üst bilişsel düzeydeki davranışları ölçmede yetersiz kalması çoktan seçmeli testlerin en çok eleştirilen yönleridir (Turgut ve Baykul, 2010). Bunlara çoktan seçmeli testlerle kısmi bilgi sahibi olmanın ölçülememesi de eklenebilir (Pehlivan Tunç ve Kutlu, 2014). Çünkü çoktan seçmeli testlerde puanlama $(1,0)$ yöntemiyle yapılmakta; doğru cevaba tam puan verilirken, yanlış cevaba, kısmı bilmeye, hiç bilmemeye ve soruyu boş bırakmaya 0 puan verilmektedir (Akkuş ve Baykul, 2001).

\section{Şans Başarısı}

Şans başarısı, çoktan seçmeli soruların kullanıldığı bir testte doğru yanıtların tahmine giderek doğru bulunma olasılığı olarak tanımlanmaktadır (Bulut, 2018). Şans başarısı çoktan seçmeli maddeyle ölçülen özelliğe sahip olmayan ya da kısmen sahip olan yanıtlayıcıların doğru yanıtı tahmin yoluyla buldukları durumda ortaya çıkmaktadır (Baykul, 2000).

Çoktan seçmeli testlerde yanıtlayıcı davranışlarını incelediği bir araştırmada Umay (1995), yanıtlayıcıların çoğunun doğru yanıtı bulduğunu düşünerek soruyu işaretlediği, doğru yanıtı bulduğuna inanmadığında ise boş bırakmayı tercih ettiğini tespit etmiştir. Aynı araştırmada, yanlışların belli bir oranda doğruları eksiltmesi belirtildiğinde aşırı bir eliminasyonun ortaya çıktığı belirtilmiştir.

Çoktan seçmeli testlerde şans başarısını ortadan kaldırmaya yönelik birçok yöntem denenmiştir. $\mathrm{Bu}$ yöntemlerde seçenekleri farklı şekillerde ağırlıklandırarak puanlamanın yanında farklı ölçme teorileriyle karşılaştırmalı çalışmalar da yer almaktadır.

Madde puanlama türlerinden $(1,0)$ ile puanlama, uzman kanısına dayalı puanlama ve güçlük düzeylerine göre çeldiricileri de işaretleyen yanıtlayıcılara puan verilen Zinger $Z_{1}$ ve Zinger $Z_{2}$ puanlama yöntemleri kullanılarak yapılan araştırmanın sonucunda Akkuş ve Baykul (2001), dört yöntemden de elde edilen sonuçların geçerlik ve güvenirlik açısından fark oluşturmadığını tespit etmişlerdir. Dolayısıyla $(1,0)$ puanlama yöntemi yerine diğer yöntemleri kullanmanın bir yararı olmayacağı sonucuna varmışlar ve farklı puanlama yöntemlerinin Klasik Test Kuramı dışındaki test teorilerinde de denenmesini önermişlerdir.

Akyıldız ve Şahin (2017), Açıköğretim Sistemi’nde 150.000'den fazla öğrenenin katıldığg bir sınavın Klasik Test Kuramı ile Madde Tepki Kuramı'na göre ölçeklenmesinden 
elde edilen öğrenen yetenek ölçüleri arasında son derece yüksek ve anlamlı bir ilişki bulmuşlar ve bu iki kuramın birbirinin yerine kullanılamayacağını belirtmişlerdir.

Bütün bu araştırmalar çoktan seçmeli testlerden elde edilen puanları şans başarısından arındırma konusunda tatmin edici ideal bir yöntemin olmadığını göstermektedir.

\section{Madde analizi}

Çoktan seçmeli testlerde her bir soru madde olarak adlandırılır. Çoktan seçmeli bir maddede genel olarak madde kökü, bir doğru cevap ve seçenek sayısına bağlı olarak da farklı sayıda çeldirici yer alır. Madde analizi, uygulanan bir testin yeterince güvenilir ve geçerli olup olmadığı, testi oluşturan maddelerin iyi çalışıp çalışmadığg, konuyu bilenler ile bilmeyenleri birbirinden ayırıp ayırmadığı, güçlügü ya da kolaylığı gibi özelliklerin belirlenmesine yarar (Gelbal, 2013). Madde analizi hesaplamada yaygın olarak kullanılan iki yöntem vardır. Bunlar, basit yöntem ve Henrysson yöntemidir. Basit yöntemde, tüm yanıtlayıcıların toplam puanlarından en başarılı \%27'lik üst ve en başarısız \%27'lik alt grup belirlenerek, kitlenin \%54'lük kısmı kullanılırken, Henrysson yönteminde ölçmeye dahil edilen tüm yanıtlayıcılar kullanılır (Hasançebi vd., 2020). Grafik 1.'de madde analizi tablosundan bir kesit verilmiştir.

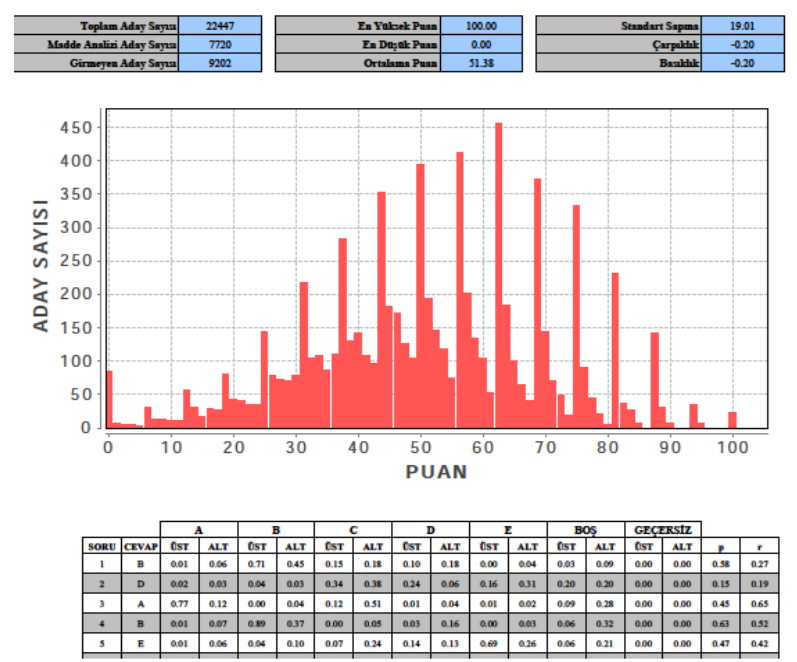

Grafik 1. Madde Analizi Tablosu

Madde analizi tablosunda üst bölümde testi alan aday sayısı, madde analizine katılan aday sayısı, alınan en yüksek ve en düşük puan, ortalama, standart sapma, çarpıklık ve basıklık değerleri yer almaktadır. Orta bölümde adayların notlara dağılımını gösteren grafik yer alırken alt bölümde madde numarası, madde için belirlenen doğru cevap, \%27'lik üst ve \%27'lik alt 
grubun seçeneklere dağılımı ve madde güçlük indeksi (p) ile madde ayırt edicilik indeksi (r) değerleri bulunur.

0 ile 1 arasında değer alan madde güçlük indeksi maddeyi üst ve alt gruplarda doğru yanıtlayanların sayısının tüm yanıtlayıcıların sayısına bölünmesiyle hesaplanır ve bulunan değer 0'a ne kadar yakınsa madde o kadar zor, 1'e ne kadar yakınsa madde o kadar kolay olarak yorumlanır. Madde ayırt edicilik indeksi (r) ise -1 ile 1 arasında değer alır ve maddeyi üst grupta doğru yanıtlayanların sayısından alt grupta doğru yanıtlayanların sayısı çıkarılıp alt ya da üst gruptan herhangi birinin eleman sayısına bölünmesiyle elde edilir. Bu değer 1'e ne kadar yakınsa maddenin ayırt edicilik gücü o derecede yüksek, sıfıra ne kadar yakınsa maddenin ayırt edicilik gücü o derece düşüktür (Gelbal, 2013). Ayırt edicilik indeksinin negatif değer alması maddenin alt grup lehine ayırt edicilik gücüne sahip olduğunu ve bu maddenin performansının sorgulanması gerektiğini gösterir.

\section{Yöntem}

\section{Araştırma Modeli}

$\mathrm{Bu}$ araştırma, nicel araştırma modellerinden ilişkisel tarama modeline uygun olarak gerçekleştirilmiştir. Karasar (2012)'a göre tarama modelleri, geçmişte ya da halen var olan bir durumu var olduğu şekilde betimlemeyi amaçlayan araştırma yaklaşımlarıdır. İlişkisel tarama modelinde iki ve daha çok sayıdaki değişken arasında birlikte değişim varlığı ve/veya derecesi belirlenmeye çalış1lır (Karasar, 2012). Bu araştırmada; soruların güçlük düzeyi, sınav dönemi ve ders türü değişkenleri ile madde analizi verilerine göre üst ve alt grupta yer alan öğrenenlerin soruları boş bırakmaları arasındaki ilişki araştırıldığı için bu model benimsenmiştir.

\section{Verilerin Toplanması}

Araştırmada, Anadolu Üniversitesi Açıköğretim Sistemi’nde yüz yüze gerçekleştirilen 2019-2020 öğretim yılı güz dönemi ara ve dönem sonu sınavlarında 6 derse ait madde analizi verileri kullanılarak veri seti oluşturulmuştur. Sözel içerikli dersler A, B ve C olarak, sayısal içerikli dersler ise $\mathrm{D}$, E ve F harfleriyle kodlanmıştır. Bu derslerde ara ve dönem sonu sınavları madde analizlerinde üst ve alt gruplarda soruların boş bırakılma oranları Tablo 1'de verilmiştir. 


\begin{tabular}{|c|c|c|c|c|c|}
\hline \multirow{2}{*}{ Ders } & \multirow{2}{*}{$\begin{array}{l}\text { Ders } \\
\text { Türü }\end{array}$} & \multicolumn{2}{|c|}{$\begin{array}{c}\text { Ara Sınavda Boş Bırakma } \\
\text { Oranı }(\%)\end{array}$} & \multicolumn{2}{|c|}{$\begin{array}{c}\text { Dönem Sonu Sınavında Boş } \\
\text { Bırakma Oranı (\%) }\end{array}$} \\
\hline & & Üst Grup & Alt Grup & Üst Grup & Alt Grup \\
\hline A & Sözel & 0,03 & 0,17 & 0,04 & 0,17 \\
\hline B & Sözel & 0,12 & 0,20 & 0,16 & 0,22 \\
\hline $\mathrm{C}$ & Sözel & 0,12 & 0,19 & 0,13 & 0,24 \\
\hline D & Sayısal & 0,19 & 0,31 & 0,15 & 0,30 \\
\hline E & Sayısal & 0,09 & 0,27 & 0,21 & 0,25 \\
\hline $\mathrm{F}$ & Sayısal & 0,12 & 0,37 & 0,23 & 0,30 \\
\hline
\end{tabular}

\section{Verilerin Analizi}

Araştırmada seçilen derslerde soruların sınav dönemine göre güçlük düzeyleri açısından karşılaştırmalarında bağımsız örneklem t-testinden yararlanılmış, üst ve alt gruptaki öğrenenlerin ara ve dönem sonu sınavlarında ders bazında boş bırakma oranlarının karşılaştırılması için Spearman Sıralama Korelasyonu kullanılmıştır. Sayısal ve sözel içerikli derslerde grupların boş bırakma oranlarının karşılaştırılmasında ise bağımsız örneklem ttestinden ve oransal dağılım grafiklerinden yararlanılmıştır.

\section{Bulgular ve Yorumlar}

Araştırmada incelenen derslerin ara ve dönem sonu sınavları madde analizlerinden elde edilen testlerin güçlük ortalamaları Tablo 2‘de verilmiştir.

\begin{tabular}{|c|c|c|c|}
\hline \multicolumn{4}{|c|}{$\begin{array}{l}\text { Tablo } 2 \\
\text { Araştırmada Seçilen Dersle } \\
\text { Güçlük Ortalamaları }\end{array}$} \\
\hline Ders & $\begin{array}{l}\text { Ders } \\
\text { Türü }\end{array}$ & $\begin{array}{c}\text { Ara Sinav Testi } \\
\text { Güçlük Ortalaması }\end{array}$ & $\begin{array}{c}\text { Dönem Sonu Sınavı } \\
\text { Testi Güçlük Ortalaması }\end{array}$ \\
\hline A & Sözel & 0,58 & 0,58 \\
\hline B & Sözel & 0,46 & 0,39 \\
\hline $\mathrm{C}$ & Sözel & 0,44 & 0,38 \\
\hline $\mathrm{D}$ & Sayısal & 0,39 & 0,43 \\
\hline E & Sayısal & 0,51 & 0,37 \\
\hline F & Sayısal & 0,43 & 0,25 \\
\hline
\end{tabular}


Tablo 2'deki veriler incelendiğinde; A dersinde ara ve dönem sonu sınavı testlerinin aynı güçlükte olduğu, B, C, E ve F derslerinde ara sınav testlerinin ortalamalarının dönem sonu testlerinin ortalamasına göre daha yüksek olduğu görülmektedir. Buna göre, B, C, E ve F derslerinin ara sınavlarının dönem sonu sınavlarına göre daha kolay olduğu söylenebilir. D dersinde ise bu durumun tersi söz konusu olup dönem sonu sınavı ortalaması ara sinav ortalamasından daha yüksektir. Madde analizi verilerine göre, F dersi dönem sonu sınavı hariç, diğer derslerin ara ve dönem sonu testlerinin orta ve kolay güçlükte olduğu söylenebilir.

Soruların güçlük düzeylerinin sözel ve sayısal içerikli derslerde farklılık gösterip göstermediğini belirlemek amacıyla sözel içerikli derslerdeki soruların güçlük ortalamaları ile sayısal içerikteki derslerdeki soruların güçlük ortalamaları tespit edilmiş ve bu ortalamaların anlamlı farklılık gösterip göstermediği t testi ile analiz edilmiştir. Elde edilen bulgular Tablo 3 'te gösterilmiştir.

\begin{tabular}{|c|c|c|c|c|c|c|c|}
\hline \multicolumn{8}{|l|}{ Tablo 3} \\
\hline \multicolumn{8}{|c|}{ Sözel ve Sayısal Derslerde Ara ve Dönem Sonu Sinavlarında Soruların Güçlük } \\
\hline \multicolumn{8}{|c|}{ Düzeyleri Ortalamalarının Karşılaştırılması İçin t-Testi Tablosu } \\
\hline & Ders Türü & $\mathrm{N}$ & Ortalama & $\begin{array}{c}\text { Standart } \\
\text { Sapma }\end{array}$ & $\mathrm{t}$ & df & $\mathrm{p}$ \\
\hline \multirow{2}{*}{ Ara Sinav } & Sözel & 60 & .4927 & .16637 & \multirow{2}{*}{1.612} & \multirow[b]{2}{*}{118} & \multirow{2}{*}{.632} \\
\hline & Sayısal & 60 & 3512 & 17574 & & & \\
\hline \multirow{2}{*}{$\begin{array}{l}\text { Dönem Sonu } \\
\text { Sinavı }\end{array}$} & Sözel & 60 & .4518 & .21392 & \multirow{2}{*}{2.817} & \multirow{2}{*}{118} & \multirow{2}{*}{.133} \\
\hline & Sayısal & 60 & .3512 & .17574 & & & \\
\hline
\end{tabular}

Tablo 3'te görüleceği gibi, derslerin ara ve dönem sonu sınavlarında soruların ortalama güçlük düzeyleri açısından istatistiksel olarak anlamlı bir fark bulunmamıştır. Buna göre, ortalama soru güçlüğü bakımından sayısal içerikli derslerin sözel içerikli derslerden daha zor olduğunu söylemek mümkün değildir.

A dersinin ara sınavında üst ve alt gruplar arasında soruları boş bırakma davranışı bakımından ilişkiyi gösteren korelasyon analizi sonucu Tablo 4'te verilmiştir. 


\begin{tabular}{|c|c|c|c|c|}
\hline \multirow{2}{*}{\multicolumn{5}{|c|}{$\begin{array}{l}\text { Tablo } 4 \\
\text { A Dersi Ara Sınavında Üst ve Alt Grubun Sc } \\
\text { Arasındaki Ilişki İçin Korelasyon Tablosu }\end{array}$}} \\
\hline & & & & (3) \\
\hline \multirow{3}{*}{ Üst Grup Boş Bırakma Oranı (1) } & rho & 1.000 & $.650^{* *}$ & $-.819^{* *}$ \\
\hline & $\mathrm{p}$ & & .002 & .000 \\
\hline & $\mathrm{N}$ & 20 & 20 & 20 \\
\hline \multirow{3}{*}{ Alt Grup Boş Bırakma Oranı (2) } & rho & $.650^{* *}$ & 1.000 & $-.515^{*}$ \\
\hline & $\mathrm{p}$ & .002 &. & .020 \\
\hline & $\mathrm{N}$ & 20 & 20 & 20 \\
\hline \multirow{3}{*}{ Soru Güçlüğü (3) } & rho & $-.819^{* *}$ & $-.515^{*}$ & 1.000 \\
\hline & $\mathrm{p}$ & .000 & .020 &. \\
\hline & $\mathrm{N}$ & 20 & 20 & 20 \\
\hline
\end{tabular}

Tablo 4'teki veriler incelendiğinde, A dersi ara sınavında üst ve alt grupta yer alan öğrenenlerin soruların güçlüğü arttıkça soruları boş bırakma eğiliminde oldukları görülmektedir. Bununla birlikte, korelasyon katsayıları ayrıntılı incelendiğinde, üst gruptaki öğrenenlerin sorular kolaylaştıkça soruları boş bırakma oranının alt gruptaki öğrenenlere oranla daha az olduğunu söylemek mümkündür. Başka bir ifadeyle, sorular zorlaştıkça alt gruptaki öğrenenler üst gruptaki öğrenenlere oranla daha fazla boş bırakmaktadırlar. A dersinin dönem sonu sınavında üst ve alt gruplar arasında soruları boş bırakma davranışı bakımından ilişkiyi gösteren korelasyon analizi sonucu Tablo 5 'te verilmiştir.

\begin{tabular}{|c|c|c|c|c|}
\hline \multicolumn{5}{|c|}{$\begin{array}{l}\text { Tablo } 5 \\
\text { A Dersi Dönem Sonu Sinavında Üst ve Alt Grubun Soruları Boş Bırakma } \\
\text { Davranışları Arasındaki İlişki İçin Korelasyon Tablosu }\end{array}$} \\
\hline & & (1) & (2) & (3) \\
\hline \multirow{3}{*}{ Üst Grup Boş Bırakma Oranı (1) } & rho & 1.000 & $.801^{* *}$ & $-.728^{* *}$ \\
\hline & $\mathrm{p}$ & & .000 & .000 \\
\hline & $\mathrm{N}$ & 20 & 20 & 20 \\
\hline \multirow{3}{*}{ Alt Grup Boş Bırakma Oranı (2) } & rho & $.801^{* *}$ & 1.000 & -.291 \\
\hline & $\mathrm{p}$ & .000 &. & .214 \\
\hline & $\mathrm{N}$ & 20 & 20 & 20 \\
\hline \multirow{3}{*}{ Soru Güçlüğü (3) } & rho & $-.728^{* *}$ & -.291 & 1.000 \\
\hline & $\mathrm{p}$ & .000 & .214 &. \\
\hline & $\mathrm{N}$ & 20 & 20 & 20 \\
\hline
\end{tabular}

Tablo 5'e göre, A dersi dönem sonu sinavinda üst ve alt grupta yer alan öğrenenler soruların güçlüğü arttıkça soruları boş bırakma oranları da artmıştır. Bununla birlikte, üst gruptaki öğrenenlerin sorular kolaylaştıkça soruları boş bırakma oranının alt gruptaki 
öğrenenlere oranla daha az olduğu görülmektedir. Başka bir deyişle, alt gruptaki öğrenenler sorular zorlaştıkça üst gruptaki öğrenenlere oranla daha fazla boş bırakmaktadırlar.

B dersi ara sınavında üst ve alt gruplar arasında soruları boş bırakma davranışı bakımından ilişkiyi gösteren korelasyon analizi sonucu Tablo 6' da verilmiştir.

\begin{tabular}{|c|c|c|c|c|}
\hline \multicolumn{5}{|c|}{$\begin{array}{l}\text { Tablo } 6 \\
\text { B Dersi Ara Sınavında Üst ve Alt Grubun Soruları Boş Bırakma Davranışlar } \\
\text { Arasındaki İlişki İçin Korelasyon Tablosu } \\
\end{array}$} \\
\hline & & (1) & (2) & (3) \\
\hline \multirow{3}{*}{ Üst Grup Boş Bırakma Oranı (1) } & rho & 1.000 & $.457^{*}$ & $-.875^{* *}$ \\
\hline & $\mathrm{p}$ & & .043 & .000 \\
\hline & $\mathrm{N}$ & 20 & 20 & 20 \\
\hline \multirow{3}{*}{ Alt Grup Boş Bırakma Oranı (2) } & rho & $.457^{*}$ & 1.000 & -.389 \\
\hline & $\mathrm{p}$ & .043 & & .090 \\
\hline & $\mathrm{N}$ & 20 & 20 & 20 \\
\hline \multirow{3}{*}{ Soru Güçlüğü (3) } & rho & $-.875^{* *}$ & -.389 & 1.000 \\
\hline & $\mathrm{p}$ & .000 & .090 & . \\
\hline & $\mathrm{N}$ & 20 & 20 & 20 \\
\hline
\end{tabular}

Tablo 6'da görüldüğü üzere B dersi ara sınavında soruların güçlük derecesinin artmasıyla üst ve alt gruplarda soruları boş bırakma oranı da artmıştır. Alt grupta boş bırakma oranı üst gruba göre daha fazladır. B dersinin dönem sonu sınavında üst ve alt gruplar arasında soruları boş bırakma davranışı bakımından ilişkiyi gösteren korelasyon analizi sonucu Tablo 7'de verilmiştir.

\begin{tabular}{|c|c|c|c|c|}
\hline \multicolumn{5}{|c|}{$\begin{array}{l}\text { Tablo } 7 \\
\text { B Dersi Dönem Sonu Sınavında Üst ve Alt Grubun Soruları Boş Bırakma } \\
\text { Davranışları Arasındaki İlişki İçin Korelasyon Tablosu }\end{array}$} \\
\hline & & (1) & (2) & (3) \\
\hline \multirow{3}{*}{ Üst Grup Boş Bırakma Oranı (1) } & rho & 1.000 & $.608^{* *}$ & $-.806^{* *}$ \\
\hline & $\mathrm{p}$ & & .004 & .000 \\
\hline & $\mathrm{N}$ & 20 & 20 & 20 \\
\hline \multirow{3}{*}{ Alt Grup Boş Bırakma Oranı (2) } & rho & $.608^{* *}$ & 1.000 & -.380 \\
\hline & $\mathrm{p}$ & .004 &. & .098 \\
\hline & $\mathrm{N}$ & 20 & 20 & 20 \\
\hline \multirow{3}{*}{ Soru Güçlüğü (3) } & rho & $-.806^{* *}$ & -.380 & 1.000 \\
\hline & $\mathrm{p}$ & .000 & .098 & . \\
\hline & $\mathrm{N}$ & 20 & 20 & 20 \\
\hline
\end{tabular}

Tablo 7'deki korelasyon sonuçları incelendiğinde, B dersi dönem sonu sınavında üst ve alt gruplarda soruların güçlük düzeyi arttıkça boş bırakma oranının da arttığı görülmüştür. Alt grupta soruları boş bırakma oranı üst gruba göre daha fazla gerçekleşmiştir. 
C dersi ara sınavında üst ve alt gruplar arasında soruları boş bırakma davranışı bakımından ilişkiyi gösteren korelasyon analizi sonucu Tablo 8'de verilmiştir.

\begin{tabular}{|c|c|c|c|c|}
\hline \multicolumn{5}{|c|}{$\begin{array}{l}\text { Tablo } 8 \\
\text { C Dersi Ara Sınavında Üst ve Alt Grubun Soruları Boş Bırakma Davranışlar } \\
\text { Arasındaki İlişki İçin Korelasyon Tablosu }\end{array}$} \\
\hline & & (1) & $(2)$ & (3) \\
\hline \multirow{3}{*}{ Üst Grup Boş Bırakma Oranı (1) } & rho & 1.000 & $.916^{* *}$ & $-.870^{* *}$ \\
\hline & $\mathrm{p}$ & & .000 & .000 \\
\hline & $\mathrm{N}$ & 20 & 20 & 20 \\
\hline \multirow{3}{*}{ Alt Grup Boş Bırakma Oranı (2) } & rho & $.916^{* *}$ & 1.000 & $-.894^{* *}$ \\
\hline & $\mathrm{p}$ & .000 & & .000 \\
\hline & $\mathrm{N}$ & 20 & 20 & 20 \\
\hline \multirow{3}{*}{ Soru Güçlüğü (3) } & rho & $-.870^{* *}$ & $-.894^{* *}$ & 1.000 \\
\hline & $\mathrm{p}$ & .000 & .000 & . \\
\hline & $\mathrm{N}$ & 20 & 20 & 20 \\
\hline
\end{tabular}

Tablo 8'deki veriler incelendiğinde, C dersi ara sınavında üst ve alt grupta yer alan öğrenenlerin soruların güçlüğü arttıkça soruları boş bırakma eğilimlerinin de arttığı görülmektedir. Alt grupta yer alan öğrenenler üst gruptakilere göre daha fazla sayıda soruyu boş bırakmışlardır. C dersinin dönem sonu sınavında üst ve alt gruplar arasında soruları boş bırakma davranışı bakımından ilişkiyi gösteren korelasyon analizi sonucu Tablo 9'da verilmiştir.

\begin{tabular}{|c|c|c|c|c|}
\hline \multicolumn{5}{|c|}{$\begin{array}{l}\text { Tablo } 9 \\
\text { C Dersi Dönem Sonu Sinavında Üst ve Alt Grubun Soruları Boş Bırakma } \\
\text { Davranışları Arasındaki İlişki İçin Korelasyon Tablosu }\end{array}$} \\
\hline & & (1) & (2) & (3) \\
\hline \multirow{3}{*}{ Üst Grup Boş Bırakma Oranı (1) } & rho & 1.000 & $.900^{* *}$ & -.355 \\
\hline & $\mathrm{p}$ & & .000 & .124 \\
\hline & $\mathrm{N}$ & 20 & 20 & 20 \\
\hline \multirow{3}{*}{ Alt Grup Boş Bırakma Oranı (2) } & rho & $.900^{* *}$ & 1.000 & -.131 \\
\hline & $\mathrm{p}$ & .000 & . & .582 \\
\hline & $\mathrm{N}$ & 20 & 20 & 20 \\
\hline \multirow{3}{*}{ Soru Güçlüğü (3) } & rho & -.355 & -.131 & 1.000 \\
\hline & $\mathrm{p}$ & .124 & .582 & . \\
\hline & $\mathrm{N}$ & 20 & 20 & 20 \\
\hline
\end{tabular}

Tablo 9'daki korelasyon sonuçları incelendiğinde, C dersi dönem sonu sınavında üst ve alt gruplarda soruların güçlük düzeyi arttıkça boş bırakma oranının da arttığı görülmüştür. Alt grupta soruları boş bırakma oranı üst gruba göre daha fazla gerçekleşmiştir. 
D dersi ara sınavında üst ve alt gruplar arasında soruları boş bırakma davranışı bakımından ilişkiyi gösteren korelasyon analizi sonucu Tablo 10'da verilmiştir.

\begin{tabular}{|c|c|c|c|c|}
\hline $\begin{array}{l}\text { Tablo } 10 \\
\text { D Dersi Ara Sınavıında Üst ve } \\
\text { Arasındaki Illişki İçin Korelas }\end{array}$ & Irub & ruları & rakm & ranışları \\
\hline & & (1) & (2) & (3) \\
\hline & rho & 1.000 & $.695^{* *}$ & $-.844^{* *}$ \\
\hline Üst Grup Boş Bırakma Oranı (1) & $\mathrm{p}$ & & .001 & .000 \\
\hline & $\mathrm{N}$ & 20 & 20 & 20 \\
\hline & rho & $.695^{* *}$ & 1.000 & -.397 \\
\hline Alt Grup Boş Bırakma Oranı (2) & $\mathrm{p}$ & .001 & . & .083 \\
\hline & $\mathrm{N}$ & 20 & 20 & 20 \\
\hline & rho & $-.844^{* *}$ & -.397 & 1.000 \\
\hline Soru Güçlüğü (3) & $\mathrm{p}$ & .000 & .083 & . \\
\hline & $\mathrm{N}$ & 20 & 20 & 20 \\
\hline
\end{tabular}

Tablo 10'daki korelasyon sonuçları incelendiğinde, D dersi ara sınavında üst ve alt gruplarda soruların güçlük düzeyi arttıkça boş bırakma oranının da arttığı görülmüştür. Alt grupta soruları boş bırakma oranı sözel içerikli A, B ve C derslerindeki boş bırakma oranından daha yüksek oranda gerçekleşmiştir. Bu durum alt grupta yer alan öğrenenlerin çözüm gerektiren sorularda daha fazla boş bırakma davranışı sergiledikleri şeklinde yorumlanabilir. D dersinin dönem sonu sınavında üst ve alt gruplar arasında soruları boş bırakma davranışı bakımından ilişkiyi gösteren korelasyon analizi sonucu Tablo 11 'de verilmiştir.

\begin{tabular}{|c|c|c|c|c|}
\hline $\begin{array}{l}\text { Tablo } 11 \\
\text { D Dersi Dönem Sonu Sinavına } \\
\text { Davranısları Arasındaki İliski }\end{array}$ & tve & $\begin{array}{l}\text { rubun } \\
\text { n Table }\end{array}$ & arl $\mathrm{Bos}_{3}$ & kma \\
\hline & & (1) & (2) & (3) \\
\hline & rho & 1.000 & $.734^{* *}$ & $-.900^{* *}$ \\
\hline Üst Grup Boș Bırakma Oranı (1) & $\mathrm{p}$ & & .000 & .000 \\
\hline & $\mathrm{N}$ & 20 & 20 & 20 \\
\hline & rho & $.734^{* *}$ & 1.000 & $-.605^{* *}$ \\
\hline Alt Grup Bos Bırakma Oranı (2) & $\mathrm{p}$ & .000 & . & .005 \\
\hline & $\mathrm{N}$ & 20 & 20 & 20 \\
\hline & rho & $-.900^{* *}$ & $-.605^{* *}$ & 1.000 \\
\hline Soru Güçlüğü (3) & $\mathrm{p}$ & .000 & .005 & . \\
\hline & $\mathrm{N}$ & 20 & 20 & 20 \\
\hline
\end{tabular}

Tablo 11'deki korelasyon sonuçları incelendiğinde, D dersi dönem sonu sınavında soruların güçlük düzeyi arttıkça üst ve alt gruplarda boş bırakma oranının da arttığ 
görülmüştür. Alt grupta soruları boş bırakma oranı daha fazla gerçekleşirken her iki grup da bu sınav döneminde ara sınava göre daha az oranda soruyu boş bırakmıştır.

E dersi ara sınavında üst ve alt gruplar arasında soruları boş bırakma davranışı bakımından ilişkiyi gösteren korelasyon analizi sonucu Tablo 12'de verilmiştir.

\begin{tabular}{|c|c|c|c|c|}
\hline $\begin{array}{l}\text { Tablo } 12 \\
\text { E Dersi Ara Sinavında Üst ve } \\
\text { Arasındaki Illişki İçin Korelasy }\end{array}$ & $\begin{array}{l}\text { Frub } \\
\text { Tablo }\end{array}$ & ulart & rakmo & ranışlart \\
\hline & & (1) & (2) & (3) \\
\hline & rho & 1.000 & $.773^{* *}$ & $-.888^{* *}$ \\
\hline Üst Grup Boș Bırakma Oranı (1) & $\mathrm{p}$ & & .000 & .000 \\
\hline & $\mathrm{N}$ & 20 & 20 & 20 \\
\hline & rho & $.773^{* *}$ & 1.000 & $-.808^{* *}$ \\
\hline Alt Grup Boş Bırakma Oranı (2) & $\mathrm{p}$ & .000 & & .000 \\
\hline & $\mathrm{N}$ & 20 & 20 & 20 \\
\hline & rho & $-.888^{* *}$ & $-.808^{* *}$ & 1.000 \\
\hline Soru Güçlüğü (3) & $\mathrm{p}$ & .000 & .000 & . \\
\hline & $\mathrm{N}$ & 20 & 20 & 20 \\
\hline
\end{tabular}

Tablo 12'deki korelasyon sonuçları incelendiğinde, E dersi ara sınavında üst ve alt gruplarda soruların güçlük düzeyi arttıkça boş bırakma oranının da arttığı görülmüştür. Sayısal içerikli olan bu derste alt grubun soruları boş bırakma oranı üst gruba göre daha yüksektir. E dersinin dönem sonu sınavında üst ve alt gruplar arasında soruları boş bırakma davranışı bakımından ilişkiyi gösteren korelasyon analizi sonucu Tablo 13'te verilmiştir.

\begin{tabular}{|c|c|c|c|c|}
\hline \multicolumn{5}{|c|}{$\begin{array}{l}\text { Tablo } 13 \\
\text { E Dersi Dönem Sonu Sinavında Üst ve Alt Grubun Soruları Boş Bırakma } \\
\text { Davranışları Arasındaki İlişki İçin Korelasyon Tablosu }\end{array}$} \\
\hline & & (1) & $(2)$ & (3) \\
\hline \multirow{3}{*}{ Üst Grup Boş Bırakma Oranı (1) } & rho & 1.000 & $.546^{*}$ & $-.941^{* *}$ \\
\hline & $p$ & & .013 & .000 \\
\hline & $\mathrm{N}$ & 20 & 20 & 20 \\
\hline \multirow{3}{*}{ Alt Grup Boş Bırakma Oranı (2) } & rho & $.546^{*}$ & 1.000 & $-.510^{*}$ \\
\hline & $p$ & .013 & . & .022 \\
\hline & $\mathrm{N}$ & 20 & 20 & 20 \\
\hline \multirow{3}{*}{ Soru Güçlüğü (3) } & rho & $-.941^{* *}$ & $-.510^{*}$ & 1.000 \\
\hline & $p$ & .000 & .005 & . \\
\hline & $\mathrm{N}$ & 20 & 20 & 20 \\
\hline
\end{tabular}

Tablo 13'teki korelasyon sonuçları incelendiğinde, E dersi dönem sonu sınavında üst ve alt gruplarda soruların güçlük düzeyi arttıkça boş bırakma oranının da arttığı görülmüştür. 
Birbirine yakın olmakla birlikte alt grupta soruları boş bırakma oranı üst gruba göre daha fazla gerçekleşmiştir.

F dersi ara sınavında üst ve alt gruplar arasında soruları boş bırakma davranışı bakımından ilişkiyi gösteren korelasyon analizi sonucu Tablo 14'te verilmiştir.

\begin{tabular}{|c|c|c|c|c|}
\hline $\begin{array}{l}\text { Tablo } 14 \\
\text { F Dersi Ara Sinavında Üst ve } \\
\text { Arasındaki Iliski İçin Korelas }\end{array}$ & $\begin{array}{l}\text { Jrub } \\
\text { Tablo }\end{array}$ & ularl B & Irakma & ranışlart \\
\hline & & (1) & (2) & (3) \\
\hline & rho & 1.000 & $.771^{* *}$ & $-.872^{* *}$ \\
\hline Üst Grup Boş Bırakma Oranı (1) & $\mathrm{p}$ & & .000 & .000 \\
\hline & $\mathrm{N}$ & 20 & 20 & 20 \\
\hline & rho & $.771^{* *}$ & 1.000 & $-.799^{* *}$ \\
\hline Alt Grup Boș Bırakma Oranı (2) & $\mathrm{p}$ & .000 & 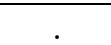 & .000 \\
\hline & $\mathrm{N}$ & 20 & 20 & 20 \\
\hline & rho & $-.872^{* *}$ & $-.799^{* *}$ & 1.000 \\
\hline Soru Güçlüğü (3) & $\mathrm{p}$ & .000 & .000 & . \\
\hline & $\mathrm{N}$ & 20 & 20 & 20 \\
\hline
\end{tabular}

Tablo 14'teki korelasyon sonuçları incelendiğinde, F dersi ara sınavında soruların güçlük düzeyi arttıkça üst ve alt gruplarda boş bırakma oranının da arttığı görülmüştür. Diğer derslerde olduğu gibi F dersi ara sınavında da alt grubun soru boş bırakma oranı üst gruptan daha fazla gerçekleşmiştir. F dersinin dönem sonu sınavında üst ve alt gruplar arasında soruları boş bırakma davranışı bakımından ilişkiyi gösteren korelasyon analizi sonucu Tablo 15'te verilmiştir.

\begin{tabular}{|c|c|c|c|c|}
\hline $\begin{array}{l}\text { Tablo } 15 \\
\text { F Dersi Dönem Sonu Sinavına } \\
\text { Davranışları Arasındaki İlişki }\end{array}$ & $\begin{array}{l}\text { t ve } \\
\text { Kor }\end{array}$ & $\begin{array}{l}\text { ubun } \\
\text { n Tab }\end{array}$ & Ir Boş & kma \\
\hline & & (1) & (2) & (3) \\
\hline & rho & 1.000 & $.770^{* *}$ & $-.717^{* *}$ \\
\hline Üst Grup Boş Bırakma Oranı (1) & $\mathrm{p}$ & & .000 & .000 \\
\hline & $\mathrm{N}$ & 20 & 20 & 20 \\
\hline & rho & $.770^{* *}$ & 1.000 & -.442 \\
\hline Alt Grup Boş Bırakma Oranı (2) & $\mathrm{p}$ & .000 & . & .051 \\
\hline & $\mathrm{N}$ & 20 & 20 & 20 \\
\hline & rho & $-.717^{* *}$ & -.442 & 1.000 \\
\hline Soru Güçlüğü (3) & $\mathrm{p}$ & .000 & .051 & . \\
\hline & $\mathrm{N}$ & 20 & 20 & 20 \\
\hline
\end{tabular}


Tablo 15'teki korelasyon sonuçları incelendiğinde, F dersi dönem sonu sınavında üst ve alt gruplarda soruların güçlük düzeyi arttıkça boş bırakma oranının da arttığı görülmüştür. Alt grupta soruları boş bırakma oranı üst gruba göre daha fazla gerçekleşmiştir.

Derslerin sözel ya da sayısal içerikli olmasına göre üst ve alt gruplarda boş bırakma oranlarına ilişkin bulgular aşağıda verilmiştir.

Ara sınav soru güçlüklerinin test içindeki dağılımları Grafik 1'de verilmiştir.

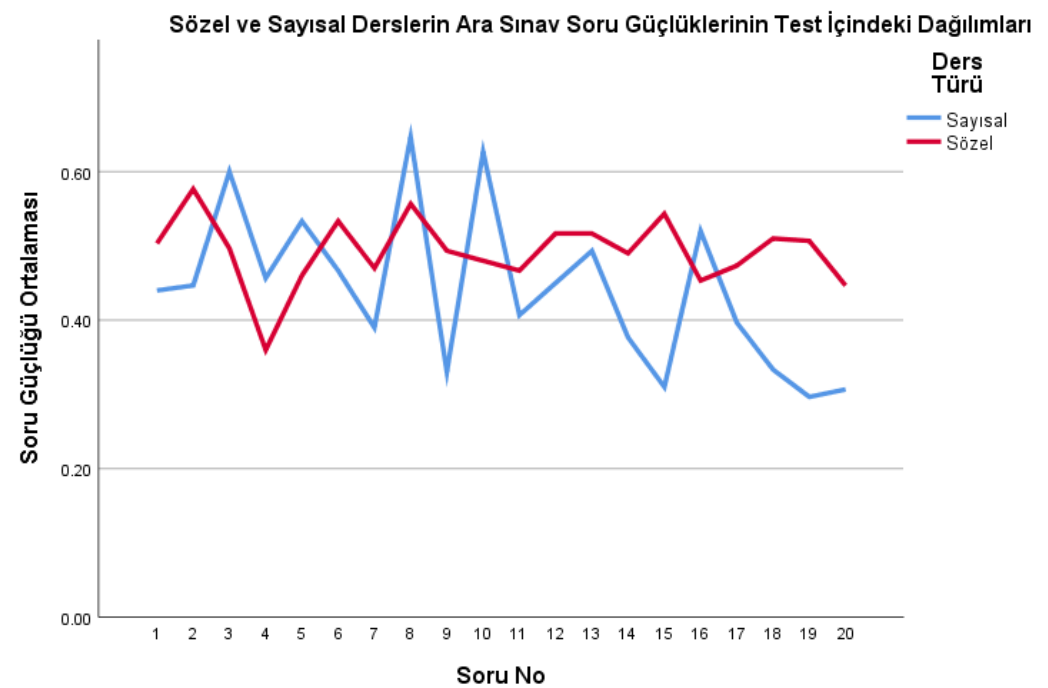

Grafik 2. Sözel ve Sayısal Derslerin Ara Sınav Soru GüçlüklerininTest İçindeki Dağılımları

Grafik 2 incelendiğinde ara sınavda yer verilen soruların güçlüğünün daha çok 0.400.60 arasında olduğu görülmektedir. Buna göre, soruların zorluk derecesinin sayısal içerikli derslerde daha fazla istisnası olmak üzere genel olarak "orta" düzeyde olduğu söylenebilir. Dönem sonu sınavında soru güçlüklerinin test içindeki dağılımı Grafik 3'te verilmiștir. 


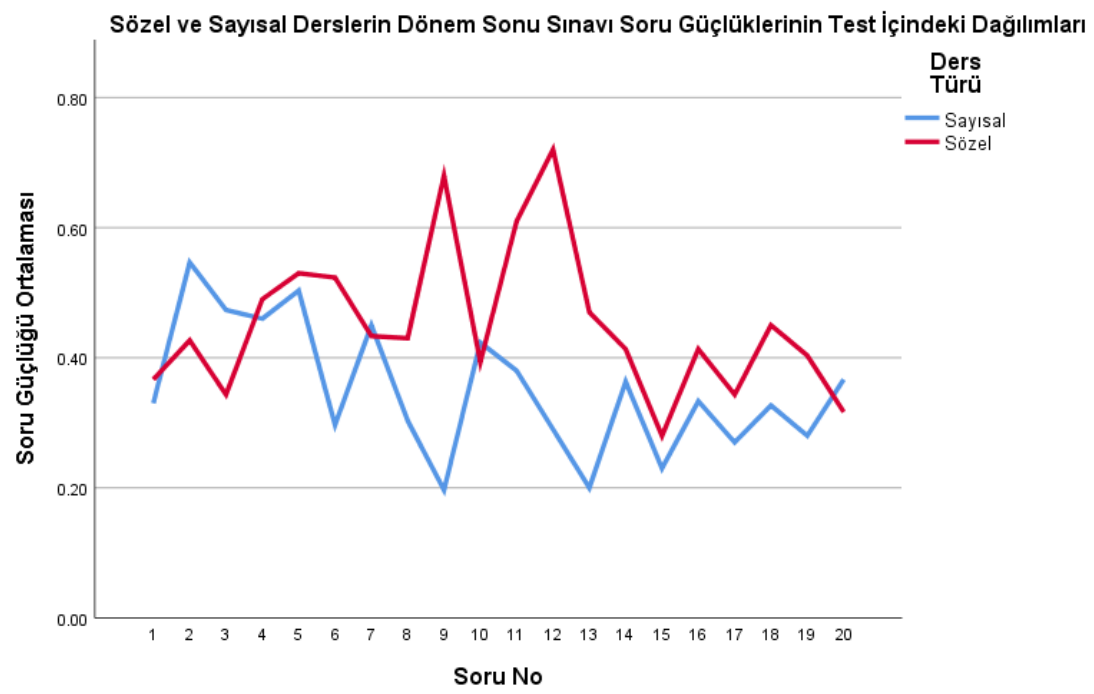

Grafik 3. Sözel ve Sayısal Derslerin Dönem Sonu Sınavı Soru Güçlüklerinin Test İçindeki Dağılımları

Grafik 3 incelendiğinde sayısal içerikli derslerde soruların önemli bir kısmının güçlük düzeyinin 0.20-0.40 arasında olduğu, sözel içerikli derslerde ise soruların güçlük düzeylerinin 0.40'ın altı ile 0.60'ın üzerinde olmak üzere daha geniş bir güçlük aralığında olduğu görülmektedir. Bu durum sayısal içerikli derslerin güçlük düzeylerinin sözel içerikli derslere göre daha yüksek olduğunu göstermektedir. Ayrıca her iki ders türünde de dönem sonu sınavının soru güçlüklerinin ara sınavdaki soru güçlüklerinden daha yüksek olduğu, dolayısıyla dönem sonu sınavının öğrenenler açısından daha zor olduğu söylenebilir. Sözel ve sayısal içerikli derslerde ara sınavın soru güçlüklerinin standart sapma dağılımları Grafik 4'te verilmiştir.

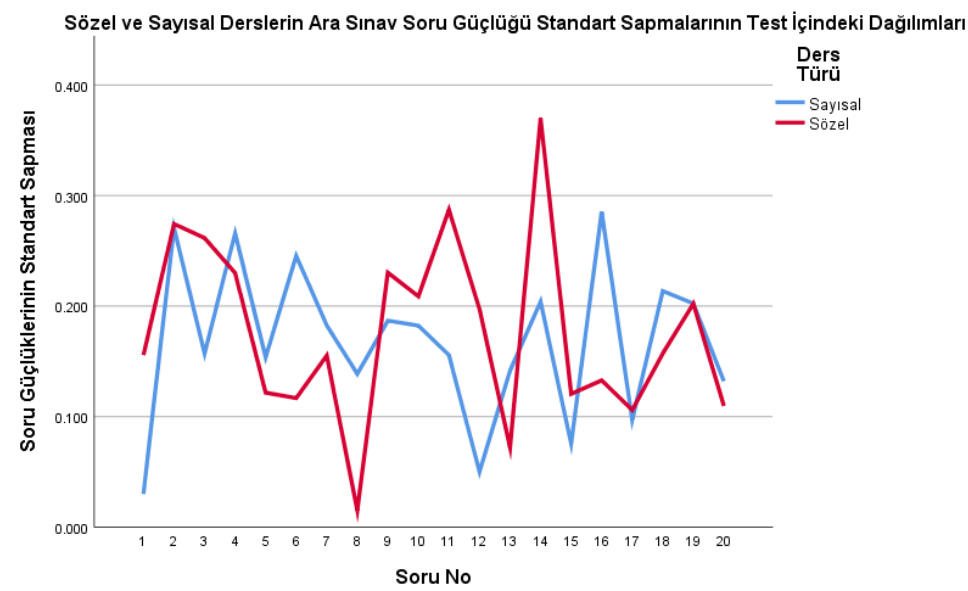

Grafik 4. Sözel ve Sayısal Derslerin Ara Sınav Soru Güçlüğü Standart Sapmalarının Test İçindeki Dağılımları 
Soru güçlüklerinin ortalamadan ne kadar uzak olduğunu belirten standart sapma değerlerinin ara sınavda test içinde dağılımını gösteren Grafik 4 incelendiğinde sözel içerikli derslerde standart sapma değerlerinin sayısal içerikli derslerdekine göre daha fazla değişkenlik gösterdiği görülmektedir. Bu durum sözel içerikli derslerde soruların zorluk derecelerinin daha fazla farklılık gösterdiği şeklinde yorumlanabilir. Sözel ve sayısal içerikli derslerde dönem sonu sınavının soru güçlüklerinin standart sapma dağılımları Grafik 5'te verilmiştir.

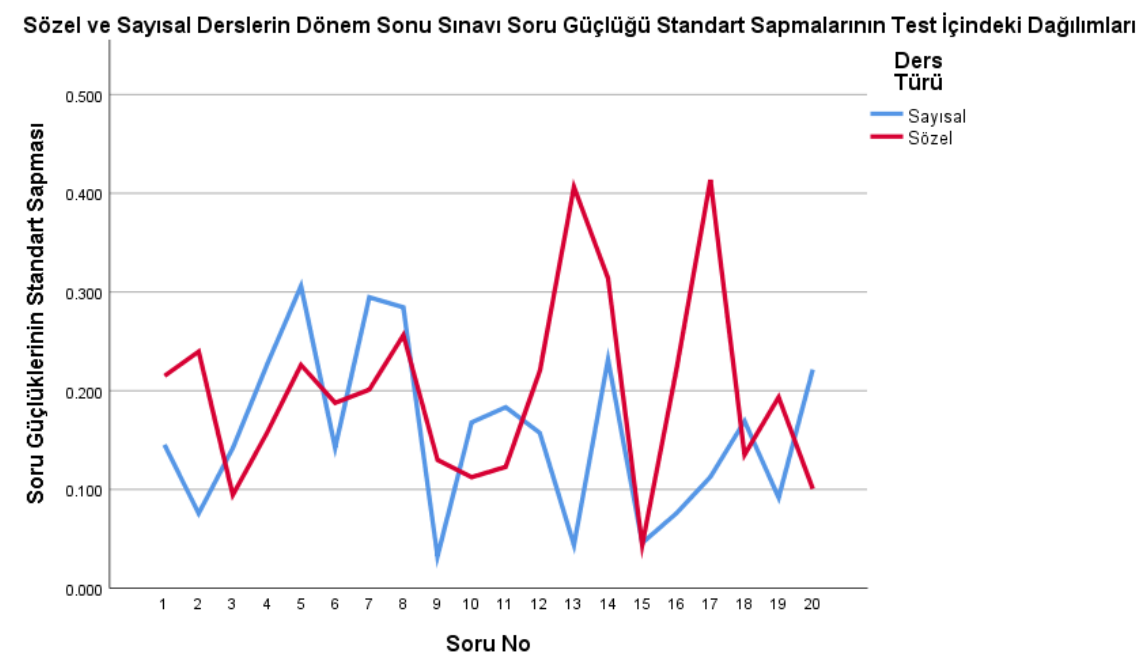

Grafik 5. Sözel ve Sayısal Derslerin Dönem Sonu Sınavı Soru Güçlüğü Standart Sapmalarının Test İçindeki Dağılımları

Grafik 5 incelendiğinde, sözel içerikli derslerde standart sapma değerlerinin özellikle testin ikinci yarısında (10-20.sorular) değişkenlik gösterdiği görülmektedir. Bu soruları cevaplayan öğrenenlerin aldıkları puanlar açısından heterojen bir yapıyı oluşturdukları söylenebilir. Sayısal içerikli derslerdeki standart sapmaların dağılımında ise ara sınavda olduğu düzeyde bir değişkenlik gözlenmemiştir.

Sözel ve sayısal içerikli derslerde ara sınavda üst gruptaki öğrenenlerin boş bırakma oranlarının test içindeki dağılımı Grafik 6'da verilmiştir. 


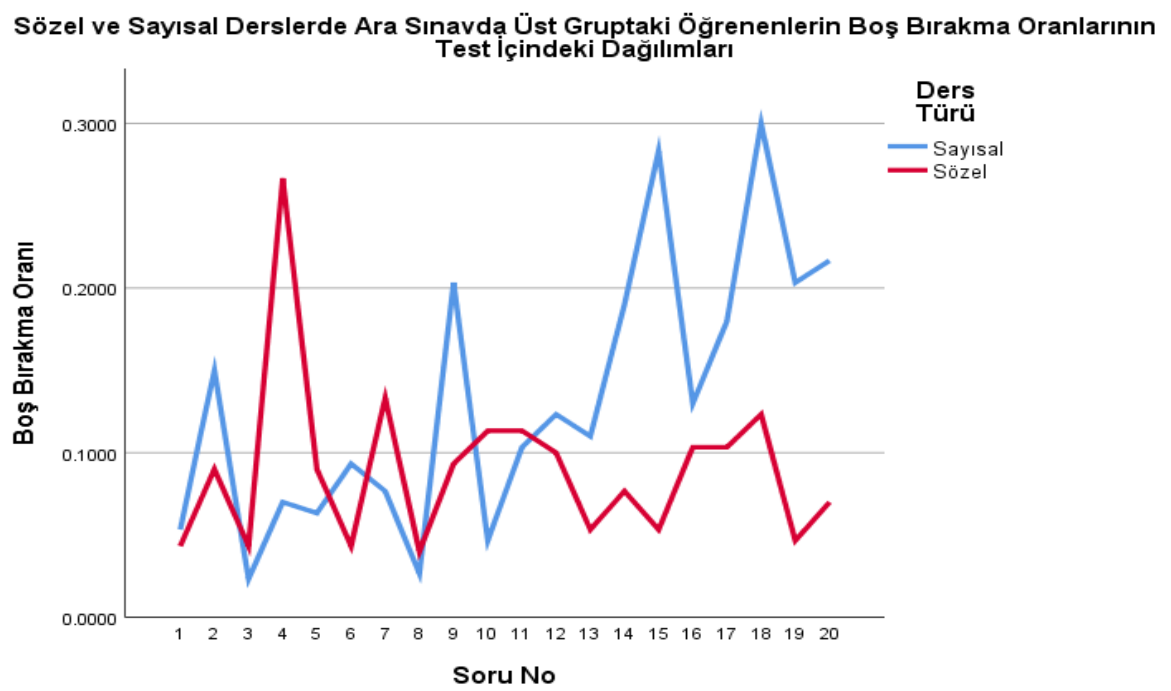

Grafik 6. Sözel ve Sayısal Derslerde Ara Sınavda Üst Gruptaki Öğrenenlerin Boş Bırakma Oranlarının Test İçindeki Dağılımları

Grafik 6 incelendiğinde, üst grupta yer alan öğrenenlerin sayısal içerikli derslerde testin sonuna doğru boş bırakma oranlarının arttı̆̆ 1 , sözel içerikli derslerde ise 3-5. sorularda boş bırakma oranının yüzde 20'nin üzerine çıktığı görülmektedir. Grafik bir bütün olarak değerlendirildiğinde üst grubun sayısal içerikli derslerde sözel içerikli derslere oranla daha fazla soruyu boş bıraktığı söylenebilir.

Sözel ve sayısal içerikli derslerde ara sınavda alt gruptaki öğrenenlerin boş bırakma oranlarının test içindeki dağılımı Grafik 7'de verilmiştir.

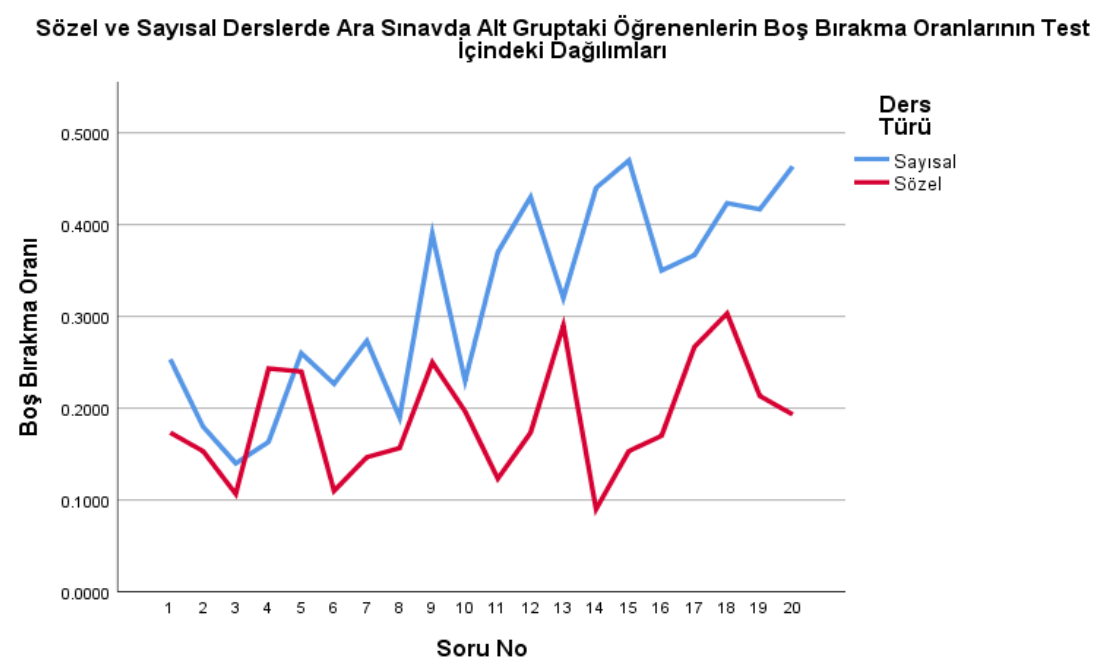

Grafik 7. Sözel ve Sayısal Derslerde Ara Sınavda Alt Gruptaki Öğrenenlerin Boş Bırakma Oranlarının Test İçindeki Dağılımları 
Grafik 7 incelendiğinde, alt gruptaki öğrenenlerin sayısal içerikli derslerde boş bırakma oranlarının sözel içerikli derslere göre daha yüksek olduğu görülmektedir. Bu da alt gruptaki öğrenenlerin sayısal içerikli derslerde soruları cevaplamada daha fazla zorluk yaşadıkları şeklinde yorumlanabilir.

Sözel ve sayısal içerikli derslerde dönem sonu sınavında üst gruptaki öğrenenlerin boş bırakma oranlarının test içindeki dağılımı Grafik 8'de verilmiştir.

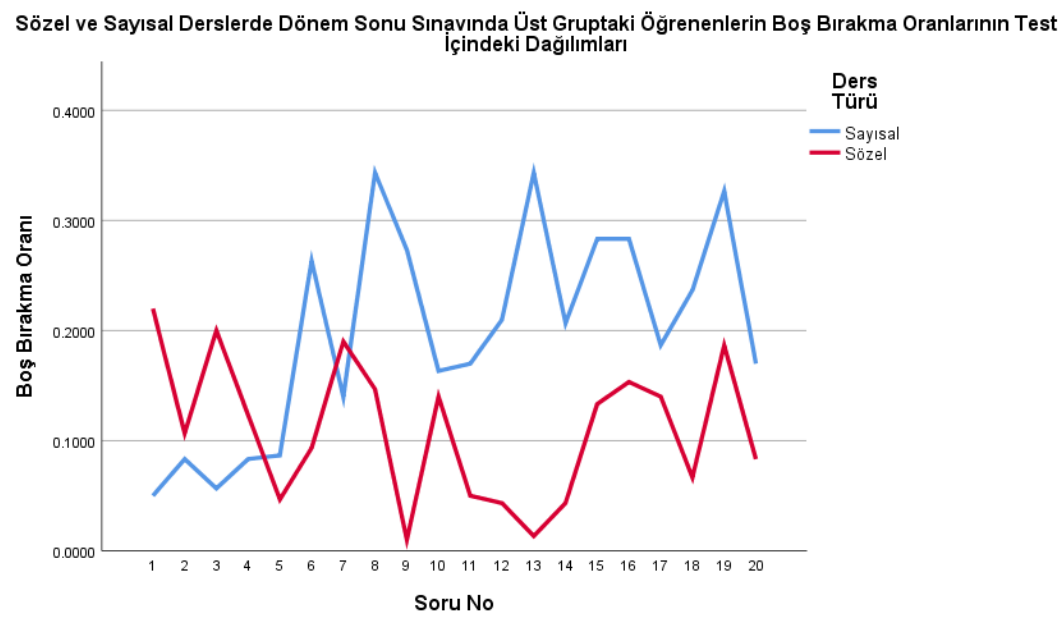

Grafik 8. Sözel ve Sayısal Derslerde Dönem Sonu Sınavında Üst Gruptaki Öğrenenlerin Boş Bırakma Oranlarının Test İçindeki Dağılımları

Grafik 8 incelendiğinde, üst gruptaki öğrenenlerin dönem sonu sinavinda sözel derslerdeki boş bırakma oranlarının sayısal derslere göre daha düşük olduğu görülmektedir. Sayısal içerikli derslerde boş bırakma oranı testin ikinci yarısında biraz daha yüksektir. Bu durum dönem sonu sınavında ders içeriğinin tamamından sorumlu olmaları nedeniyle öğrenenlerin tüm konulardaki hâkimiyetinin yeterli olmamasıyla açıklanabilir.

Grafik 9'da alt gruptaki öğrenenlerin dönem sonu sınavında soruları boş bırakma oranlarının test içindeki dağılımları verilmiştir. 


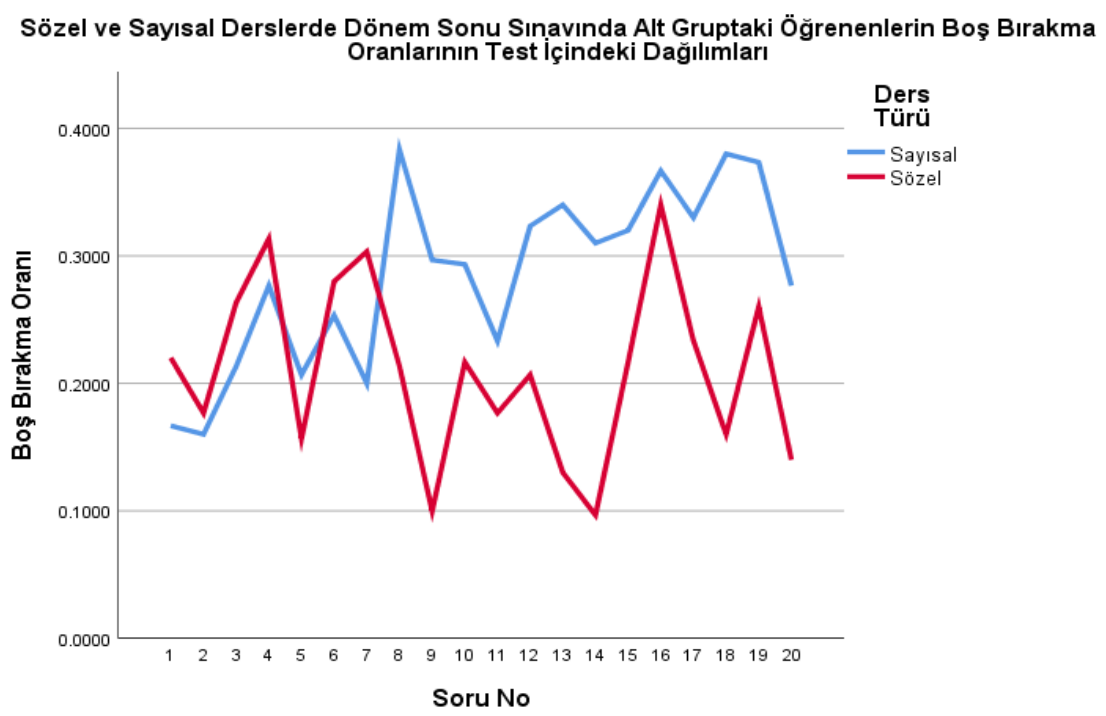

Grafik 9. Sözel ve Sayısal Derslerde Dönem Sonu Sınavında Alt Gruptaki Öğrenenlerin Boş Bırakma Oranlarının Test İçindeki Dağılımları

Grafik 9 incelendiğinde, alt grupta yer alan öğrenenlerin dönem sonu sinavinda sözel içerikli derslerde soruları boş bırakma oranı sayısal içerikli derslere göre daha düşüktür. Alt gruptaki öğrenenler özellikle sayısal içerikli derslerde hakkında bilgi sahibi olmadıkları soruları daha yüksek oranda boş bırakma eğilimi göstermiştir.

Sözel ve sayısal içerikli derslerde üst ve alt gruplarda ara sınavda soruların boş bırakılma oranlarını karşılaştırmak için yapılan bağımsız gruplar için t-testi sonuçları Tablo 16'da verilmiştir.

\begin{tabular}{|c|c|c|c|c|c|c|c|}
\hline \multicolumn{8}{|c|}{$\begin{array}{l}\text { Sözel ve Sayısal Derslerin Üst ve Alt Gruplarda Ara Sınavda Boş Bırakılma } \\
\text { Oranlarının Karşılaştırılması İçin t-Testi Tablosu }\end{array}$} \\
\hline Grup & Ders Türü & $\mathrm{N}$ & Ortalama & $\begin{array}{c}\text { Standart } \\
\text { Sapma } \\
\end{array}$ & $\mathrm{t}$ & $\overline{D f}$ & $\mathrm{p}$ \\
\hline \multirow{2}{*}{ Üst Grup } & Sözel & 60 & . 090000 & .1099769 & \multirow{2}{*}{-1.802} & \multirow{2}{*}{118} & \multirow{2}{*}{.055} \\
\hline & Sayısal & 60 & .132333 & .1450350 & & & \\
\hline \multirow{2}{*}{ Alt Grup } & Sözel & 60 & .187667 & .0953916 & \multirow{2}{*}{5.394} & \multirow{2}{*}{118} & \multirow{2}{*}{$.000^{*}$} \\
\hline & Sayısal & 60 & .317833 & .1607513 & & & \\
\hline
\end{tabular}

*p $<0.05$

Tablo 16'da görüleceği gibi ara sınavda sözel ve sayısal içerikli derslerde boş bırakma oranlarının üst grupta anlamlı bir farklılık göstermediği tespit edilmiştir. Alt grupta ise 
öğrenenlerin sözel içerikli derslerde daha az boş bırakma davranışı sergiledikleri, sayısal içerikli derslerde boş bırakma oranlarının daha yüksek olduğu gözlenmiştir $\left(\mathrm{t}_{118-0.05}=-5.394\right)$.

Sözel ve sayısal içerikli derslerde üst ve alt gruplarda dönem sonu sınavında soruların boş bırakılma oranlarını karşılaştırmak için yapılan bağımsız gruplar için t-testi sonuçları Tablo 17'de verilmiştir.

\begin{tabular}{|c|c|c|c|c|c|c|c|}
\hline \multicolumn{8}{|c|}{$\begin{array}{l}\text { Sözel ve Sayısal Derslerde Üst ve Alt Gruplarda Dönem Sonu Sınavında Soruların } \\
\text { Boş Bırakılma Oranlarının Karşılaştırılması İçin t-Testi Tablosu }\end{array}$} \\
\hline Grup & Ders Türü & $\mathrm{N}$ & Ortalama & $\begin{array}{c}\text { Standart } \\
\text { Sapma } \\
\end{array}$ & $\mathrm{t}$ & $\mathrm{df}$ & $\mathrm{p}$ \\
\hline \multirow{2}{*}{ Üst Grup } & Sözel & 60 & .109500 & .1089460 & \multirow{2}{*}{-3.707} & \multirow{2}{*}{118} & \multirow{2}{*}{$.002 *$} \\
\hline & Sayısal & 60 & .198000 & .1494374 & & & \\
\hline \multirow{2}{*}{ Alt Grup } & Sözel & 60 & .210167 & .1062535 & \multirow{2}{*}{-3.871} & \multirow[b]{2}{*}{118} & \multirow{2}{*}{.975} \\
\hline & Sayısal & 60 & .285167 & .1059660 & & & \\
\hline
\end{tabular}

${ }^{*} \mathrm{p}<0.05$

Tablo 17'de görüleceği gibi sözel ve sayısal içerikli derslerde dönem sonu sınavında boş bırakma oranlarının üst grupta istatistiksel olarak anlamlı bir farklılık gösterdiği tespit edilmiştir ( $\left.\mathrm{t}_{118-0.05}=-3.707\right)$. Buna göre; üst grupta yer alan öğrenenlerin sözel içerikli derslerde daha az boş bırakma davranışı sergiledikleri, sayısal içerikli derslerde boş bırakma oranlarının daha yüksek olduğu gözlenmiştir. Alt grupta yer alan öğrenenlerin sözel içerikli derslerde boş bırakma oranları ile sayısal içerikli derslerde boş bırakma oranları arasında istatistiksel olarak anlamlı bir fark bulunamamıştır. $\mathrm{Bu}$ durum da alt gruptaki öğrenenlerin ders türü gözetmeksizin hakkında herhangi bir fikri olmadıkları soruları boş bıraktıkları şeklinde yorumlanabilir. 


\section{Sonuçlar}

Bu çalışmada, Açıköğretim Sistemi’nde yer alan 6 derste 2019-2020 Güz dönemi ara ve dönem sonu sınavı madde analizi verilerine göre üst ve alt gruplarda yer alan öğrenenlerin çoktan seçmeli sınavlarda soruları boş bırakma durumları incelenmiştir. Bunun için $A, B, C$ sözel dersleri ile D, E, F sayısal derslerinin madde analizlerinde verilen boş bırakma oranları kullanılmıştır.

A, B, C, D, E ve F derslerinin ara ve dönem sonu sınavlarında soruların ortalama güçlük düzeyleri açısından istatistiksel olarak anlamlı bir fark bulunmamıştır. Bu sonuç, ortalama soru güçlüğü bakımından sayısal içerikli derslerin sözel içerikli derslerden zorluk açısından farklı olmadığını göstermiştir.

Çalışmada ulaşılan önemli sonuçlardan biri incelenen derslerin tamamında alt grupta yer alan öğrenenlerin üst gruptaki öğrenenlere göre daha fazla boş bırakma eğilimine sahip olmalarıdır. Bu sonuç, Umay(1995)'ın araştırmasında ortaya çıkan yanıtlayıcıların çoğunun doğru yanıtı bulduğunu düşünerek soruyu işaretlediği, doğru yanıtı bulduğuna inanmadığında ise boş bırakmayı tercih ettiği tespitiyle örtüşmektedir.

Çalışmada incelenen sözel içerikli derslerde (A, B ve C dersleri) hem alt hem de üst gruptaki öğrenenler dönem sonu sınavında ara sınava göre daha çok boş bırakma davranışı gösterirken, sayısal içerikli derslerde (D, E ve F dersleri) alt grupta yer alan öğrenenler ara sınava göre dönem sonu sınavında daha fazla boş bırakmışlardır. Üst grupta yer alan öğrenenler sayısal içerikli derslerden sadece D dersinin dönem sonunda daha fazla oranda boş bırakma davranışı sergilemiştir. Dönem sonu sınavının genel değerlendirme içindeki oranının \%70 olduğu göz önünde bulundurulduğunda bu sonuç normal karşılanmayabilir.

Sözel ya da sayısal içerikli olduğu fark etmeksizin çalışma kapsamında incelenen tüm derslerde soruların güçlük düzeyleri arttıkça üst ve alt gruplarda soruları boş bırakma eğiliminin artması dört yanlışın bir doğruyu eksiltmesi uygulamasının öğrenenlerin yanıtlama davranışlarını değiştirdiğini göstermektedir. Bu sonuç, farklı derslerde ve sınav yöntemlerinde şans başarısına düzeltme formülünün uygulanacağının açıklandığı ve açıklanmadığı durumlarda öğrenenlerin ortaya koydukları performansın incelendiği Betts vd. (2009)'in araştırmasının sonuçlarıyla da örtüşmektedir. Betts vd. (2009), şans başarısına yönelik düzeltme formülü uygulanmadığında öğrenenlerin daha az boş bırakma davranışı sergilediklerini ve daha yüksek puanlar aldıklarını ortaya koymuştur. 


\section{Öneriler}

Çalışma sonunda aşağıdaki öneriler geliştirilmiştir:

- Çalışmanın daha fazla dersin dâhil edilerek yapılması farklı sonuçların elde edilmesini sağlayabilir.

- Dört yanlışın bir doğruyu eksiltmesi uygulamasının ilk dönemlerindeki yanıtlayıcı davranışları ile sonraki dönemdeki yanıtlayıcı davranışları arasında fark olup olmadığı araştırılabilir.

- Çoktan seçmeli testlerde çeldiricilerin işlerliğine yönelik araştırmalar yapılarak madde analizi sonuçları daha detaylı incelenebilir.

- Sınava katılan öğrenenlerin bazılarıyla soruları yanıtlama davranışlarının derinlemesine incelenmesi için görüşmeler yapılabilir. 


\section{Kaynakça}

Adiga, M. N. S., Acharya, S. ve Holla, R. (2021). Item analysis of multiple-choice questions in pharmacology in an Indian Medical School. Journal of Health and Allied Sciences NU. Doi: https://doi.org/ 10.1055/s-0041-1722822.

Akkuş, O. ve Baykul, Y. (2001). Çoktan seçmeli test maddelerini puanlamada seçenekleri farklı biçimlerde ağırlıklandırmanın madde ve test istatistiklerine olan etkisinin incelenmesi. Hacettepe Üniversitesi Ĕ̈itim Fakültesi Dergisi (20), 9 -15.

Akyıldız, M. ve Şahin, M. D. (2017). Açıköğretimde kullanılan sınavlardan Klasik Test Kuramına ve Madde Tepki Kuramına göre elde edilen yetenek ölçülerinin karşılaştırılması, Açıköğretim Uygulamaları ve Araştırmaları Dergisi (AUAd), 3(4), 141159.

Baykul, Y. (2000). Eğitimde ve psikolojide ölçme: Klasik test teorisi ve uygulaması. Ankara: ÖSYM Yayınları.

Baykul, Y. (1992). Eğitim sisteminde değerlendirme. Hacettepe Üniversitesi Ĕ̆itim Fakültesi Dergisi, (7), 85-94.

Betts, L. R., Elder, T. J., E., Hartley, J. ve Trueman, M. (2009). Does correction for guessing reduce students' performance on multiple-choice examinations? Yes? No? Sometimes?, Assessment \& Evaluation in Higher Education, 34(1), 1-15. Doi: $10.1080 / 02602930701773091$

Bulut, G. (2018). Açık ve uzaktan öğrenmede şans başarısı: Klasik Test Kuramı (KTK) ve Madde Tepki Kurama (MTK) temelinde karşılaştırmalı bir analiz. AUAd, 4(1), 78-93.

Chaudhary, S. ve Dey, N. (2013). Assessment in open and distance learning system (ODL): A Challenge. Open Praxis, 5(3), 207-216.

Demirel, Ö. (2007). Eğitimde program geliştirme. Ankara: Pegem A Yayıncılık.

Gelbal, S. (2013). Ölçme ve değerlendirme. Ankara: Saray Matbaacılık.

Hasançebi, B., Terzi, Y. ve Küçük, Z. (2020). Madde Güçlük İndeksi ve Madde Ayırt Edicilik İndeksine Dayalı Çeldirici Analizi. Gümüşhane Üniversitesi Fen Bilimleri Enstitüsü Dergisi, 10 (1), 224-240.

Karadağ, N. ve Özgür, A. Z. (2020). Assessment and evaluation in mega universities. TOJET: The Turkish Online Journal of Educational Technology, 19(4), 35-49.

Karasar, N. (2012). Bilimsel araştırma yöntemi. Ankara: Nobel Yayın Dağıtım.

Miller, M., Linn, R. ve Gronlund, N. (2012). Measurement and assessment in teaching. (11th Ed.). Columbus: Pearson.

Özkul, A.E. ve Aydın, C.H. (2012). Öğrenci adaylarının açık ve uzaktan öğrenmeye yönelik görüşleri. Akademik Bilişim 2012. https://ab.org.tr/ab12/bildiri/42.pdf 
Pehlivan Tunç, E. B. ve Kutlu, Ö. (2014). Türkçe test maddelerinde yanıtlama davranışlarının incelenmesi. Eğitimde ve Psikolojide Ölçme ve Değerlendirme Dergisi, (5,1), 61-71.

Simonson, M., Smaldino, S., Albright, M. ve Zvacek, S. (2012). Teaching and learning at a distance: Foundations of distance education (3rd ed.). New Jersey: Prentice Hall.

Turgut, M. F. ve Baykul, Y. (2010). Eğitimde ölçme ve değerlendirme. Ankara: Pegem Yayıncilik.

Umay, A. (1997). Yanıtlayıcı davranışlarının analizi yolu ile matematikte problem çözümleri için bir güvenirlik ve geçerlik araştırması. Hacettepe Üniversitesi Eğitim Fakültesi Dergisi (13), 47-56.

Umay, A. (1995). Seçmeli testlerde yanıtlayıcı davranışları ve şans başarısının elimine edilmesi işlemlerine ilişkin bazı öneriler. II. Ĕ̌gitim Bilimleri Kongresi. Ankara.

Yurdabakan, İ. (2012). Bloom'un revize edilen taksonomisinin eğitimde ölçme ve değerlendirmeye etkileri. Gaziantep Üniversitesi Sosyal Bilimler Dergisi,11(2), $327-$ 348.

Zhang, W.Y., Tsui, C., Jegede, O., Ng, F. ve Kwok, L. (2000). A comparison of distance education in selected Asian open universities. In Proceedings of the 20th Conference of the Asian Association of Open Universities, 25-27. 


\section{Yazar Hakkında}

Nejdet KARADAĞ

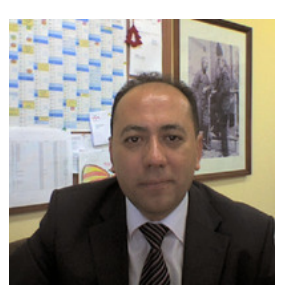

Nejdet KARADAĞ, lisans eğitimini Anadolu Üniversitesi Eğitim Fakültesi Fransızca Öğretmenliği Bölümünde yapmıştır. Yüksek lisans ve doktora eğitimini Anadolu Üniversitesi Sosyal Bilimler Enstitüsü Uzaktan Eğitim Anabilim Dalı'nda tamamlamıştır. 2015 yılından bu yana Açıöğretim Fakültesi Test Araştırma Birimi yöneticisi olarak görev yapmaktadır. İlgi alanları açık ve uzaktan öğrenmede ölçme değerlendirme, öğretim tasarımı ve mega üniversitelerdir.

Posta adresi: Tel (İş): GSM:

Anadolu Üniversitesi Açıköğretim Fakültesi, Yunusemre Kampüsü, Eskişehir, Türkiye 26470 +90 $2223350580 / 2716$ +90 5055604942

Eposta: nkaradag@anadolu.edu.tr 